Article

\title{
New Azaphilones, Seco-Chaetomugilins A and D, Produced by a Marine-Fish-Derived Chaetomium globosum
}

\author{
Takeshi Yamada *, Yasuhide Muroga and Reiko Tanaka
}

Osaka University of Pharmaceutical Sciences, 4-20-1, Nasahara, Takatsuki, Osaka 569-1094, Japan; E-Mail: tanakar@gly.oups.ac.jp (R.T.)

* Author to whom correspondence should be addressed; E-Mail: yamada@glu.oups.ac.jp; Tel.: +8172-690-1085; Fax: +81-72-690-1084

Received: 18 May 2009; in revised form: 11 June 2009 / Accepted: 15 June 2009 /

Published: 16 June 2009

\begin{abstract}
Seco-chaetomugilins A and D were isolated from a strain of Chaetomium globosum that was originally isolated from the marine fish Mugil cephalus, and their absolute stereostructures were elucidated on the basis of spectroscopic analyses, including 1D and 2D NMR techniques, along with the chemical transformation from known chaetomugilins A and D. Seco-chaetomugilin D exhibited growth inhibitory activity against cultured P388, HL-60, L1210, and KB cells.
\end{abstract}

Keywords: fungus; marine-fish; Chaetomium globosum; cytotoxicity; chaetomugilins; azaphilones; chemical transformation; alkaline degradation

\section{Introduction}

Marine microorganisms are potentially prolific sources of highly bioactive secondary metabolites that might serve as useful leads in the development of new pharmaceutical agents. Based on the fact that some of the bioactive materials isolated from marine animals have been produced by bacteria, we have focused our attention on new antitumor agents from microorganisms separated from marine organisms [1-5]. As part of this endeavor, we have conducted a search for antitumor compounds from a strain of Chaetomium globosum OUPS-T106B-6 that was originally isolated from the marine fish Mugil cephalus, and have reported six new cytotoxic metabolites designated as chaetomugilins A (1), 
$\mathrm{B}, \mathrm{C}, \mathrm{D}(2), \mathrm{E}$, and $\mathrm{F}$ from the culture broth of this fungal strain [6,7]. These compounds are azaphilones and they display various bioactivities, including antimicrobial, nitric oxide inhibitory, gp120-CD4 binding inhibitory, monoamine oxidase inhibitory, and platelet-derived growth factor binding inhibitory properties [7]. An examination of a disease-oriented panel of 39 human cancer cell lines (HCC panel) [8,9] suggested the possibility that the mode of action of chaetomugilins A (1), C, and $\mathrm{F}$ might be different from that shown by any other anticancer drugs developed to date [7]. Our continuing search for cytotoxic metabolites from this fungal strain yielded two new azaphilones designated as seco-chaetomugilins A (3) and D (4) (Figure 1). Seco-chaetomugilin D (4) exhibited significant cytotoxic activity against the murine P388 leukemia cell line, the human HL-60 leukemia cell line, the murine L1210 leukemia cell line, and the human KB epidermoid carcinoma cell line. We describe herein the absolute stereostructures and biological activities of these compounds.

Figure 1. Structures of compounds 1-4.
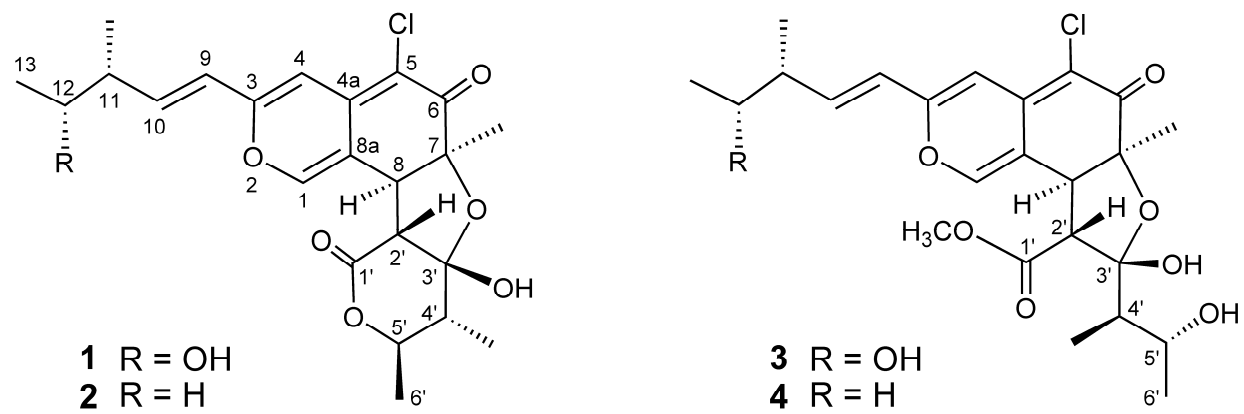

\section{Results and Discussion}

C. globosum was cultured at $27^{\circ} \mathrm{C}$ for six weeks in a medium $(100 \mathrm{~L})$ containing $1 \%$ soluble starch and $0.1 \%$ casein in $50 \%$ artificial seawater adjusted to $\mathrm{pH} 7.4$ as reported previously [6,7]. After incubation, the AcOEt extract of the culture filtrate was purified by bioassay-directed fractionation (cytotoxicities against P388 cell line) employing a stepwise combination of Sephadex LH-20, silica gel column chromatography, and reversed-phase HPLC (RP-HPLC) to afford seco-chaetomugilins A (3) and D (4).

Seco-chaetomugilin A (3) had the molecular formula $\mathrm{C}_{24} \mathrm{H}_{31} \mathrm{ClO}_{8}$, which was established from the $[\mathrm{M}+\mathrm{H}]^{+}$ion in high-resolution fast atom bombardment mass spectrometry (HRFABMS) and the ratio of intensity of isotope ions $\left(\mathrm{MH}^{+} /[\mathrm{MH}+2]^{+}\right)$. Its IR spectrum exhibited bands at 3,382, 1,736, and $1,642 \mathrm{~cm}^{-1}$, which are characteristic of hydroxyl, ester, and conjugated carbonyl groups, respectively. Close inspection of the ${ }^{1} \mathrm{H}$ - and ${ }^{13} \mathrm{C}-\mathrm{NMR}$ spectra (Table 1 ) of 3 by DEPT and HMQC experiments revealed the presence of four secondary methyls $\left(11-\mathrm{CH}_{3}, \mathrm{C}-13,4{ }^{\prime}-\mathrm{CH}_{3}\right.$, and $\mathrm{C}-6$ '), one tertiary methyl $\left(7-\mathrm{CH}_{3}\right)$, one ester methyl $\left(1^{\prime}-\mathrm{OCH}_{3}\right)$, four $s p^{2}$-hybridized methines $(\mathrm{C}-1, \mathrm{C}-4, \mathrm{C}-9$, and $\mathrm{C}-10)$ including oxygen-bearing carbon (C-1), six $s p^{3}$-methines (C-8, C-11, C-12, C-2', C-4' and C-5') including two oxymethines ( $\mathrm{C}-12$ and $\mathrm{C}-5$ '), two quaternary oxygen-bearing $s p^{3}$-carbon (C-7 and C-3') including a hemiketal carbon (C-3'), four quaternary $s p^{2}$-carbons (C-3, C-4a, C-5 and C-8a) including one oxygen-bearing carbon (C-3), and two carbonyls (C-6 and C-1'). ${ }^{1} \mathrm{H}-{ }^{1} \mathrm{H}$ COSY analysis of 3 revealed two partial structural units as shown by bold-faced lines in Figure 2. The geometrical 
configuration of the double bond moiety $\left(\Delta_{9}, 10\right)$ was deduced to be trans from the coupling constants of the olefinic protons $\left(J_{9,10}=15.5 \mathrm{~Hz}\right)$. The connection of these units and the remaining functional groups was determined on the basis of the key HMBC correlations summarized in Figure 2. The connection of a chlorine atom to C-5 was reasonable from its chemical shift $\left(\delta_{\mathrm{C}} 110.0\right)$. Thus, the planar structure of $\mathbf{3}$ was elucidated as shown in Figure 2.

Figure 2. Selected ${ }^{1} \mathrm{H}-{ }^{1} \mathrm{H}$ COSY and HMBC correlations of compound 3.

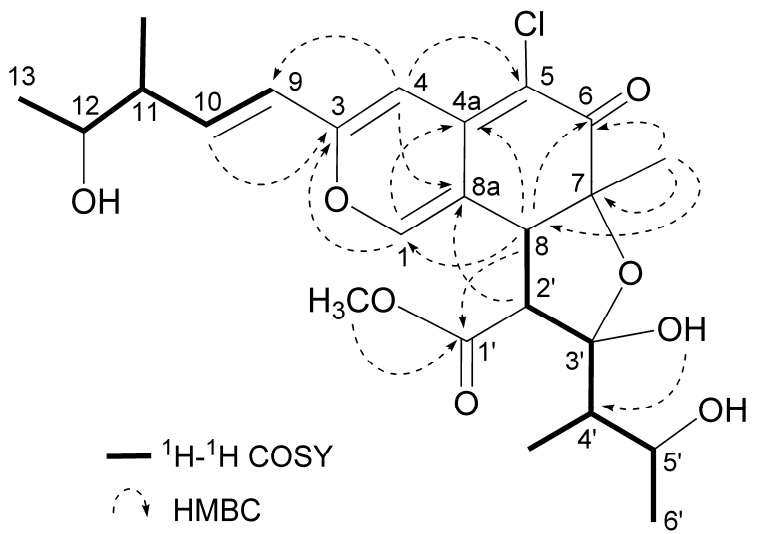

The relative stereochemistry of $\mathbf{3}$ was examined by conducting NOESY experiments. NOE correlations $\left(8-\mathrm{H} / 4\right.$ ' $-\mathrm{CH}_{3}$ and $\left.7-\mathrm{CH}_{3} / 4^{\prime}-\mathrm{CH}_{3}\right)$ implied that $8-\mathrm{H}$ is oriented cis to the 7-methyl group and C-3' - C-4' bond. However, the relative configuration of C-11, C-12, C-2', C-4' and C-5' could not be elucidated. Treatment with $p$-TsOH of chaetomugilin A (1) in $\mathrm{MeOH}$ gave chaetomugilins $\mathrm{B}$ and $\mathrm{C}$ as reported previously [6]. This time, the above reaction was carried out on the condition that more amount of $p$-TsOH was used, and then gave 3 together with chaetomugilins B and C (Scheme 1). Product $\mathbf{3}$ was confirmed to be identical to natural $\mathbf{3}$ on the basis of IR, UV, and NMR spectra and optical rotations. This result allowed us to assign the absolute configuration of all the asymmetric centers $\left(7 S, 8 S, 11 R, 12 R, 2^{\prime} R, 3^{\prime} R, 4^{\prime} R\right.$ and $\left.5^{\prime} R\right)$ in 3 . In order to confirm the absolute configuration of C-11 and C-12, alkaline degradation, which is used for the confirmation of flavone character, was applied to compound 3 . The degradation of 3 with $5 \%$ potassium hydroxide afforded a carboxylic acid that was identified as $(4 R, 5 R)-2 E-5$-hydroxy-4-methylhex-2-enoic acid by comparison of spectral data and specific optical rotation with those of carbonic acid obtained from $\mathbf{1}$ in a similar manner (Scheme 2) [10]. Thus, the absolute configuration at C-11 and C-12 of 3 were supported as $R$ and $R$, respectively.

Scheme 1. Chemical transformation from 1 and 2 to 3 and 4.

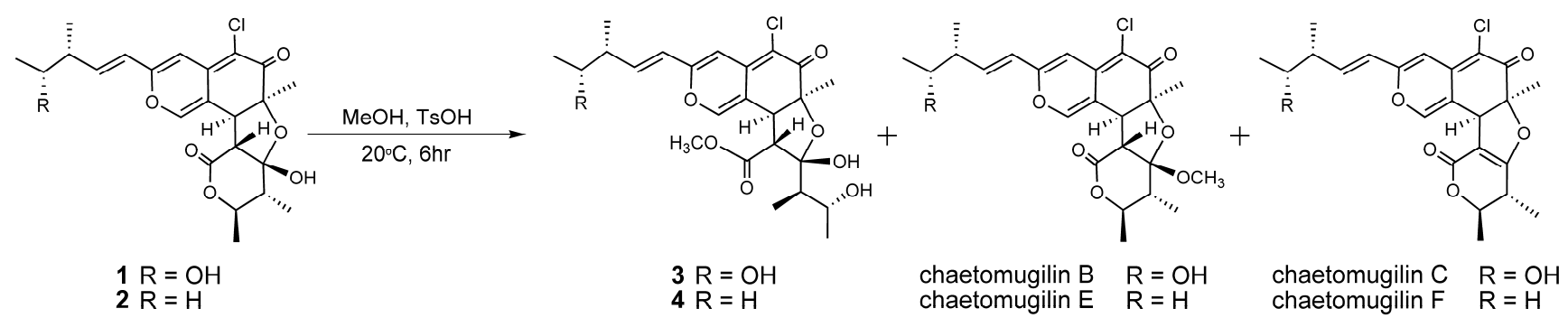


Scheme 2. Alkaline degradation of 3 and 4.

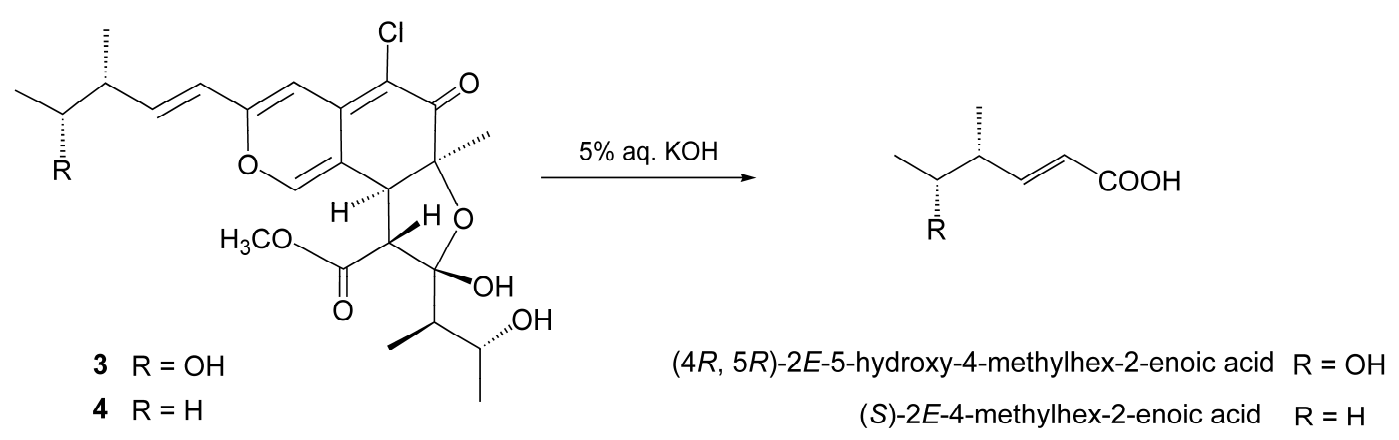

Seco-chaetomugilin D (4), which contained one oxygen atom less than 3, was assigned the molecular formula $\mathrm{C}_{24} \mathrm{H}_{31} \mathrm{ClO}_{7}$ by HRFABMS. The general features of its $\mathrm{UV}$, IR, and NMR spectra (Table 1) closely resembled those of 3 except that the proton signals for H-11 $\left(\delta_{\mathrm{H}} 2.24\right.$, sept), H-12 $\left(\delta_{\mathrm{H}} 1.42, \mathrm{~m}\right)$, and $\mathrm{H}-13\left(\delta_{\mathrm{H}} 0.89, \mathrm{t}\right)$, and the carbon signals for $\mathrm{C}-10\left(\delta_{\mathrm{C}} 146.2\right), \mathrm{C}-11\left(\delta_{\mathrm{C}} 38.8\right), \mathrm{C}-12$ $\left(\delta_{\mathrm{C}} 29.2\right), \mathrm{C}-13\left(\delta_{\mathrm{C}} 11.7\right)$, and $11-\mathrm{CH}_{3}\left(\delta_{\mathrm{C}} 19.4\right)$ in 4 revealed a chemical shift difference relative to those of 3 . The above evidence implied that the hydroxyl methine at $\mathrm{C}-12$ in 3 was replaced with a methylene in 4 . The planar structure of 4 was confirmed by analyzing ${ }^{1} \mathrm{H}-{ }^{1} \mathrm{H}$ COSY correlations and HMBC correlations. In NOESY experiments, the same NOE correlations $\left(8-\mathrm{H} / 4\right.$ ' $-\mathrm{CH}_{3}$ and $7-\mathrm{CH}_{3} / 4^{\prime}-$ $\mathrm{CH}_{3}$ ) as those of 3 were observed. As in compound 3, treatment with $p$-TsOH of 2 in $\mathrm{MeOH}$ gave product $\mathbf{4}$, which was confirmed to be identical to natural $\mathbf{4}$ on the basis of IR, UV, and NMR spectra and optical rotations. The above lines of evidence revealed the absolute stereostructure of 4 . In order to confirm the absolute configuration of $\mathrm{C}-11$, the alkaline degradation was applied to compound $\mathbf{4}$ by the above method. The degradation of $\mathbf{4}$ with $5 \%$ potassium hydroxide afforded a carboxylic acid that was identified as (S)-2E-4-methylhex-2-enoic acid by comparison of spectral data and specific optical rotation with those of a commercial sample (Scheme 2) [11]. Thus, the absolute configuration at C-11 was supported as $S$.

During the isolation process, the culture filtrate was extracted with AcOEt, and the time that $\mathbf{1}$ and $\mathbf{2}$ were exposed to $\mathrm{MeOH}$ on $\mathrm{LH}-20$ and the silica gel column chromatography was very short $(6 \sim 7 \mathrm{~h}$ being the longest time). In addition, chaetomugilins A (1) and D (2) were stable in $\mathrm{MeOH}$ for a few days. As the above reaction, only compounds $\mathbf{3}$ and $\mathbf{4}$ were obtained in low yield by treatment with $p$ TsOH of 1 and 2 in $\mathrm{MeOH}$, respectively, but not obtained by the methanolysis using conc. $\mathrm{H}_{2} \mathrm{SO}_{4}$. These evidences confirm that seco-chaetomugilins A (3) and D (4) are not artifacts of 1 and 2, respectively.

Assays for the growth inhibitory activity of other azaphilones using various cancer cell lines are rarely reported. As a primary screen for antitumor activities, the cancer cell growth inhibitory activities of $\mathbf{3}$ and $\mathbf{4}$ were examined using the murine P388 leukemia cell line, the human HL-60 leukemia cell line, the murine L1210 leukemia cell line, and the human KB epidermoid carcinoma cell line. Compound 4 exhibited moderate cytotoxicity to all cell lines $\left(\mathrm{IC}_{50}\right.$ : 38.6, 47.2, 53.6, 47.2 $\mu \mathrm{M}$, respectively). On the other hand, compound 3 showed no growth inhibition against all cell lines. These results implied that the presence of the hydroxyl group at C-12 reduced the activity. 
Table 1. ${ }^{1} \mathrm{H}$ - and ${ }^{13} \mathrm{C}-\mathrm{NMR}$ data of compounds $\mathbf{3}$ and $\mathbf{4}$ in $\mathrm{CDCl}_{3}$.

\begin{tabular}{|c|c|c|c|c|c|c|c|c|c|c|c|}
\hline \multirow{2}{*}{\multicolumn{2}{|c|}{ Position }} & \multicolumn{5}{|c|}{3} & \multicolumn{5}{|c|}{4} \\
\hline & & \multicolumn{2}{|c|}{$\delta_{\mathrm{H}}{ }^{\mathrm{a}}$} & \multirow[t]{2}{*}{$\mathrm{J} / \mathrm{Hz}$} & \multicolumn{2}{|c|}{$\delta_{\mathrm{C}}$} & \multicolumn{2}{|c|}{$\delta_{\mathrm{H}}{ }^{\mathrm{a}}$} & \multirow[t]{2}{*}{$\mathrm{J} / \mathrm{Hz}$} & \multicolumn{2}{|c|}{$\delta_{\mathrm{C}}$} \\
\hline 1 & & 7.58 & $\mathrm{~s}$ & & 146.2 & (d) & 7.58 & $\mathrm{~s}$ & & 145.9 & (d) \\
\hline 3 & & & & & 156.6 & (s) & & & & 157.1 & (s) \\
\hline 4 & & 6.49 & $\mathrm{~s}$ & & 105.1 & (d) & 6.46 & $\mathrm{~s}$ & & 104.6 & (d) \\
\hline $4 a$ & & & & & 140.3 & (s) & & & & 140.5 & (s) \\
\hline 5 & & & & & 110.0 & $(\mathrm{~s})$ & & & & 109.7 & (s) \\
\hline 6 & & & & & 188.7 & $(\mathrm{~s})$ & & & & 188.6 & (s) \\
\hline 7 & & & & & 83.1 & (s) & & & & 83.1 & (s) \\
\hline 8 & & 3.90 & $\mathrm{~d}$ & $12.0\left(2^{\prime}\right)$ & 44.3 & (d) & 3.90 & $\mathrm{~d}$ & $12.0\left(2^{\prime}\right)$ & 44.3 & (d) \\
\hline $8 \mathrm{a}$ & & & & & 114.7 & (s) & & & & 114.6 & (s) \\
\hline 9 & & 6.13 & $\mathrm{~d}$ & $15.5(10)$ & 122.3 & (d) & 6.03 & $\mathrm{~d}$ & $16.2(10)$ & 120.4 & (d) \\
\hline 10 & & 6.58 & $\mathrm{dd}$ & $\begin{array}{l}15.5(9), 7.8 \\
(11)\end{array}$ & 141.6 & (d) & 6.48 & $\mathrm{dd}$ & $\begin{array}{l}16.2(9), \\
6.1(11)\end{array}$ & 146.2 & (d) \\
\hline 11 & & 2.44 & dqd & $\begin{array}{l}7.8(10), 6.5 \\
\left(11-\mathrm{CH}_{3}\right), 6.2 \\
(12)\end{array}$ & 44.2 & (d) & 2.24 & sept & $\begin{array}{l}6.1(10,12, \\
\left.11-\mathrm{CH}_{3}\right)\end{array}$ & 38.8 & (d) \\
\hline 12 & & 3.80 & quint & $6.2(11,13)$ & 70.9 & (d) & 1.42 & $\mathrm{~m}$ & & 29.2 & $(t)$ \\
\hline 13 & & 1.19 & $\mathrm{~d}$ & $6.2(12)$ & 20.4 & (q) & 0.89 & $\mathrm{t}$ & $7.2(12)$ & 11.7 & (q) \\
\hline 7 & $-\mathrm{CH}_{3}$ & 1.48 & $\mathrm{~s}$ & & 25.3 & (q) & 1.48 & $\mathrm{~s}$ & & 25.3 & (q) \\
\hline 11 & $-\mathrm{CH}_{3}$ & 1.12 & $\mathrm{~d}$ & $6.5(11)$ & 14.9 & (q) & 1.07 & $\mathrm{~d}$ & $6.1(11)$ & 19.4 & (q) \\
\hline $1^{\prime}$ & & & & & 169.4 & (s) & & & & 169.5 & (s) \\
\hline $2^{\prime}$ & & 3.24 & $\mathrm{~d}$ & $12.0(8)$ & 53.7 & (d) & 3.24 & $\mathrm{~d}$ & $12.0(8)$ & 53.7 & (d) \\
\hline $3^{\prime}$ & & & & & 107.5 & $(\mathrm{~s})$ & & & & 107.5 & $(\mathrm{~s})$ \\
\hline $4^{\prime}$ & & 2.01 & $\mathrm{dq}$ & $\begin{array}{l}9.5\left(5^{\prime}\right), 6.8\left(4^{\prime}-\right. \\
\left.\mathrm{CH}_{3}\right)\end{array}$ & 44.7 & (d) & 2.01 & $\mathrm{dq}$ & $\begin{array}{l}9.5\left(5^{\prime}\right), 6.5 \\
\left(4^{\prime}-\mathrm{CH}_{3}\right)\end{array}$ & 44.7 & (d) \\
\hline $5^{\prime}$ & & 4.33 & $\mathrm{dq}$ & $9.5\left(4^{\prime}\right), 6.0\left(6^{\prime}\right)$ & 71.1 & (d) & 4.33 & $\mathrm{dq}$ & $\begin{array}{l}9.5\left(4^{\prime}\right), 6.1 \\
\left(6^{\prime}\right)\end{array}$ & 71.1 & (d) \\
\hline $6^{\prime}$ & & 1.30 & $\mathrm{~d}$ & $6.0\left(5^{\prime}\right)$ & 23.4 & (q) & 1.30 & $\mathrm{~d}$ & $6.1\left(5^{\prime}\right)$ & 23.4 & (q) \\
\hline $1^{\prime}$ & $-\overline{\mathrm{OCH}_{3}}$ & 3.74 & $\mathrm{~s}$ & & 52.1 & (q) & 3.74 & $\mathrm{~s}$ & & 52.1 & (q) \\
\hline $4^{\prime}$ & $-\mathrm{CH}_{3}$ & 0.83 & $\mathrm{~d}$ & $6.8\left(4^{\prime}\right)$ & 13.3 & (q) & 0.83 & $\mathrm{~d}$ & $6.5\left(4^{\prime}\right)$ & 13.2 & (q) \\
\hline $3^{\prime}$ & $-\mathrm{OH}$ & 6.75 & br s & & & & & & & & \\
\hline
\end{tabular}

\section{Experimental}

\section{General}

Melting points were determined on a Yanagimoto micro-melting point apparatus and are uncorrected. UV spectra were recorded on a Hitachi U-2000 spectrophotometer and IR spectra, on a JASCO FT/IR-680 Plus. NMR spectra were recorded at $27{ }^{\circ} \mathrm{C}$ on Varian UNITY INOVA-500 and MERCURY spectrometers with tetramethylsilane (TMS) as internal reference. FABMS were obtained 
using a JEOL JMS-700 (Ver. 2) mass spectrometer. Optical rotations were recorded on a JASCO J-820 polarimeter. Liquid chromatography over silica gel (mesh 230-400) was performed at medium pressure. HPLC was run on a Waters ALC-200 instrument equipped with a differential refractometer (R 401) and Shim-pack PREP-ODS (25 cm x $20 \mathrm{~mm}$ i. d.). Analytical TLC was performed on precoated Merck aluminum sheets (DC-Alufolien Kieselgel $60 \mathrm{~F} 254,0.2 \mathrm{~mm}$ ) with the solvent system $\mathrm{CH}_{2} \mathrm{Cl}_{2}-\mathrm{MeOH}(9: 1)$, and compounds were viewed under a UV lamp and sprayed with $10 \% \mathrm{H}_{2} \mathrm{SO}_{4}$ followed by heating.

\section{Culture and Isolation of Metabolites}

A strain of C. globosum was initially isolated from the marine fish $M$. cephalus collected in the Katsuura Bay of Japan in October 2000. The marine fish was wiped with EtOH and its gastrointestinal tract applied to the surface of nutrient agar layered in a Petri dish. Serial transfers of one of the resulting colonies provided a pure strain of C. globosum. The fungal strain was cultured at $27{ }^{\circ} \mathrm{C}$ for six weeks in a liquid medium $(100 \mathrm{~L})$ containing $1 \%$ soluble starch and $0.1 \%$ casein in $50 \%$ artificial seawater adjusted to $\mathrm{pH}$ 7.4. The culture was filtered under suction and the mycelia collected were extracted thrice with $\mathrm{MeOH}$. The combined extracts were evaporated in vacuo to give a mixture of crude metabolites $(42.8 \mathrm{~g})$, the $\mathrm{CHCl}_{3}-\mathrm{MeOH}(1: 1)$ soluble fraction of which exhibited cytotoxicity. The culture filtrate was extracted thrice with AcOEt. The combined extracts were evaporated in vacuo to afford a mixture of crude metabolites (20.6 g). The AcOEt extract was passed through Sephadex LH-20 using $\mathrm{CHCl}_{3}-\mathrm{MeOH}(1: 1)$ as eluent. The second fraction $(7.2 \mathrm{~g})$ in which the activity was concentrated was chromatographed on a silica gel column with a $\mathrm{CHCl}_{3}-\mathrm{MeOH}$ gradient as eluent. The $\mathrm{CHCl}_{3}$ eluate (1.5 g) was purified by HPLC using $\mathrm{MeCN}-\mathrm{H}_{2} \mathrm{O}(4: 1)$ as eluent to afford 4 (5.1 $\left.\mathrm{mg}\right)$, and the $\mathrm{MeOH}-\mathrm{CHCl}_{3}$ (1:99) eluate (1.8 g) was purified by $\mathrm{HPLC}$ using $\mathrm{MeOH}-\mathrm{H}_{2} \mathrm{O}(1: 1)$ as eluent to afford $3(7.8 \mathrm{mg})$ together with other chaetomugilins, respectively.

\section{Seco-chaetomugilin A (3)}

Pale yellow powder; mp $97-99{ }^{\circ} \mathrm{C}\left(\mathrm{CHCl}_{3}-\mathrm{MeOH}\right) ;[\alpha]_{\mathrm{D}}{ }^{22} 294.0\left(\right.$ c 0.09, EtOH); UV $\lambda_{\max }(\mathrm{EtOH}) /$ nm: $292(\log \varepsilon 3.86), 373$ (3.94), 405 (4.01); IR $v_{\max }(\mathrm{KBr}) / \mathrm{cm}^{-1}:$ 3,382 (OH), 1,736 (ester), 1,642 ( $\alpha$, $\beta$-unsaturated carbonyl), 1,563, 1,522 (C=C); FABMS m/z (rel. int.): $483\left([\mathrm{M}+\mathrm{H}]^{+}, 43.9 \%\right), 485$ $\left([\mathrm{M}+\mathrm{H}+2]^{+}, 16.7 \%\right)$; HRFABMS $m / z$ 483.1782 [M+H] ${ }^{+}\left(\right.$calcd for $\left.\mathrm{C}_{24} \mathrm{H}_{32}{ }^{35} \mathrm{ClO}_{8}: 483.1785\right) ;{ }^{1} \mathrm{H}-$ and ${ }^{13} \mathrm{C}-\mathrm{NMR}$ data are listed in Table 1.

\section{Seco-chaetomugilin D (4)}

Pale yellow powder; mp $97-99^{\circ} \mathrm{C}\left(\mathrm{CHCl}_{3}-\mathrm{MeOH}\right) ;[\alpha]_{\mathrm{D}}^{22} 161.3$ (c 0.13 , EtOH); UV $\lambda_{\max }(\mathrm{EtOH}) / \mathrm{nm}: 291\left(\log \varepsilon\right.$ 3.88), 371 (3.80), 411 (3.88); IR $v_{\max }(\mathrm{KBr}) / \mathrm{cm}^{-1}: 3,431(\mathrm{OH}), 1,740$ (ester), 1,622 ( $\alpha, \beta$-unsaturated carbonyl), 1,564, 1,522 $(\mathrm{C}=\mathrm{C})$; FABMS $\mathrm{m} / \mathrm{z}$ (rel. int.): $467\left([\mathrm{M}+\mathrm{H}]^{+}\right.$, $65.1 \%), 469\left([\mathrm{M}+\mathrm{H}+2]^{+}, 23.2 \%\right)$; HRFABMS $\mathrm{m} / \mathrm{z} 467.1840[\mathrm{M}+\mathrm{H}]^{+}$(calcd for $\mathrm{C}_{24} \mathrm{H}_{32}{ }^{35} \mathrm{ClO}_{7}$ : 467.1836); ${ }^{1} \mathrm{H}$ - and ${ }^{13} \mathrm{C}-\mathrm{NMR}$ data are listed in Table 1. 


\section{Derivatization of $\mathbf{3}$ from 1}

p-TsOH (32.7 mg) was added to a $\mathrm{MeOH}$ solution (5 mL) of chaetomugilin A (1) (23.7 mg) and the reaction mixture was left at room temperature for $6 \mathrm{~h}$. The solvent was evaporated under reduced pressure and the residue was purified by HPLC using $\mathrm{MeCN}-\mathrm{H}_{2} \mathrm{O}(55: 45)$ as eluent to afford 3 (3.2 mg), chaetomugilin B (6.7 mg), and chaetomugilin C (5.5 mg).

\section{Degradation of 1 by Potassium Hydroxide}

Seco-chaetomugilin A $(3,15.2 \mathrm{mg})$ was dissolved in $5 \%$ aq. potassium hydroxide $(10 \mathrm{~mL})$ and the reaction mixture was stirred for $3 \mathrm{~h}$ at $100^{\circ} \mathrm{C}$. Then, the reaction mixture was extracted with $\mathrm{CHCl}_{3}$ $(15 \mathrm{~mL})$. The water layer was adjusted to $\mathrm{pH} 3.0$ with $9 \%$ sulfuric acid and re-extracted with $\mathrm{CHCl}_{3}$ $(10 \mathrm{~mL})$. The organic extract was concentrated to dryness in vacuo. The residue was purified by HPLC using $\mathrm{MeCN}-\mathrm{H}_{2} \mathrm{O}$ gradient $(0: 100)-(60: 40)$ as the eluent to afford $(4 R, 5 R)-2 E-5$-hydroxy-4-methylhex-2-enoic acid $(0.9 \mathrm{mg})$. Using the same procedure, chaetomugilin A $(26.5 \mathrm{mg})$, the absolute stereostructure of which was determined already, was treated with $5 \%$ aq. potassium hydroxide $(20 \mathrm{~mL})$ and purified by HPLC to afford (4R,5R)-2E-5-hydroxy-4-methylhex-2-enoic acid (3.1 mg). Colorless oil; $[\alpha]_{\mathrm{D}}^{22} 90.0$ (c 0.05, EtOH); HRFABMS m/z: $145.0867[\mathrm{M}+\mathrm{H}]^{+}$(calcd for $\mathrm{C}_{7} \mathrm{H}_{13} \mathrm{O}_{3}$ : 145.0865); ${ }^{1} \mathrm{H}-\mathrm{NMR} \delta \mathrm{ppm}\left(\mathrm{CDCl}_{3}\right): 1.12\left(3 \mathrm{H}, \mathrm{d}, J=6.5 \mathrm{~Hz}, 4-\mathrm{CH}_{3}\right), 1.19(3 \mathrm{H}, \mathrm{d}, J=6.2 \mathrm{~Hz}, \mathrm{H}-6)$, $2.44(1 \mathrm{H}, \mathrm{dqd}, J=7.5,6.5,6.2 \mathrm{~Hz}, \mathrm{H}-4), 3.80(1 \mathrm{H}$, quint, $J=6.2 \mathrm{~Hz}, \mathrm{H}-5), 5.90(1 \mathrm{H}, \mathrm{d}, J=15.5 \mathrm{~Hz}$, $\mathrm{H}-2), 7.06(1 \mathrm{H}, \mathrm{d}, J=15.5,7.5 \mathrm{~Hz}, \mathrm{H}-3)$.

\section{Derivatization of $\mathbf{4}$ from 2}

Using the same procedure as above with compound 2, chaetomugilin D (2) (22.8 mg) was treated with $p$ - $\mathrm{TsOH}(27.7 \mathrm{mg})$ in $\mathrm{MeOH}(8 \mathrm{~mL})$ and the products were purified by $\mathrm{HPLC}$ using $\mathrm{MeCN}-\mathrm{H}_{2} \mathrm{O}$ (7:3) as eluent to afford 4 (3.5 mg), chaetomugilin E (8.6 mg), and chaetomugilin F (7.2 mg).

\section{Degradation of 2 by Potassium Hydroxide}

Seco-chaetomugilin $\mathrm{D}(4,16.7 \mathrm{mg})$ was dissolved in $5 \%$ aq. potassium hydroxide $(15 \mathrm{~mL})$ and the reaction mixture was stirred for $3 \mathrm{~h}$ at $100^{\circ} \mathrm{C}$. Then, the reaction mixture was extracted with $\mathrm{CHCl}_{3}$ $(15 \mathrm{~mL})$. The water layer was adjusted to $\mathrm{pH} 3.0$ with $9 \%$ sulfuric acid and re-extracted with petroleum ether $(15 \mathrm{~mL})$. The organic extract was concentrated to dryness in vacuo. The residue was purified by HPLC using $\mathrm{MeCN}-\mathrm{H}_{2} \mathrm{O}$ gradient $(0: 100)$ - (100:0) as the eluent to afford $(S)-2 E-4-$ methylhex-2-enoic acid $(0.7 \mathrm{mg})$. The physicochemical properties of this carboxylic acid were identical with those of a commercial sample [10].

\section{Assay for Cytotoxicity to the Cancer Cell Lines}

Cytotoxicity of seco-chaetomugilins A (3) and D (4) were examined by the 3-(4,5-dimethyl-2thiazolyl)-2,5-diphenyl-2H-tetrazolium bromide (MTT) method. P388, HL-60, L1210, and KB cells 
were cultured in Eagle's Minimum Essential Medium ( $10 \%$ fetal calf serum) at $37^{\circ} \mathrm{C}$ in $5 \% \mathrm{CO}_{2}$. The test material was dissolved in dimethyl sulfoxideto give a concentration of $10 \mathrm{mM}$, and the solution was diluted with the Essential Medium to give concentrations of 200, 20, and $2 \mu \mathrm{M}$, respectively. Each solution was combined with each cell suspension $\left(1 \times 10^{5}\right.$ cells $\left./ \mathrm{mL}\right)$ in the medium, respectively. After incubating at $37{ }^{\circ} \mathrm{C}$ for $72 \mathrm{~h}$ in $5 \% \mathrm{CO}_{2}$, grown cells were labeled with $5 \mathrm{mg} / \mathrm{mL}$ MTT in phosphate buffered saline (PBS), and the absorbance of formazan dissolved in $20 \%$ sodium dodecyl sulfate (SDS) in $0.1 \mathrm{~N} \mathrm{HCl}$ was measured at $540 \mathrm{~nm}$ using a microplate reader (Model 450, BIO-RAD). Each absorbance value was expressed as percentage relative to the control cell suspension that was prepared without the test substance with the same procedure as that described above. All assays were performed three times. Semilogarithmic plots were constructed from the averaged data and the effective dose of the substance required to inhibit cell growth by $50 \%\left(\mathrm{IC}_{50}\right)$ was determined.

\section{Acknowledgements}

We thank Dr. T. Ito (National Institute of Technology and Evaluation, Biological Resource Center) for identification of the fungal strain. We are grateful to Ms. M. Fujitake and Dr. K. Minoura of this university for MS and NMR measurements, respectively. In addition, we thank Dr. Y. Usami of this university for the advice on the chemical reactions. This study was supported by a Grant-in-Aid for High Technology from the Ministry of Education, Culture, Sports, Science and Technology, Japan.

\section{References and Notes}

1. Iwamoto, C.; Yamada, T.; Ito, Y.; Minoura, K.; Numata, A. Cytotoxic cytochalasans from a Penicillium species separated from a marine alga. Tetrahedron 2001, 57, 2997-3004.

2. Yamada, T.; Iritani, M.; Doi, M.; Minoura, K.; Ito, Y.; Numata, A. Absolute stereostructures of cell-adhesion inhibitors, macrosphelides C, E-G and I, produced by a Periconia species separated from an Aplysia sea hare. J. Chem. Soc. Perkin Trans. 1 2001, 3046-3053.

3. Yamada, T.; Iritani, M.; Minoura, K.; Kawai, K.; Numata, A. Peribysins A-D, potent celladhesion inhibitors from a sea hare-derived culture of Periconia species. Org. Biomol. Chem. 2004, 2131-2135.

4. Yamada, T.; Imai, E.; Nakatuji, K.; Numata, A.; Tanaka, R. Cephalimysin A, a potent cytotoxic metabolite from an Aspergillus species separated from a marine fish. Tetrahedron Lett. 2007, 48, 6294-6296.

5. Yamada, T.; Iritani, M., Ohishi, H., Tanaka, K., Minoura, K., Doi, M., Numata, A. Pericosines, antitumour metabolites from the sea hare-derived fungus Periconia byssoides. Structures and biological activities. Org. Biomol. Chem. 2007, 3079-3986 and references cited therein.

6. Yamada, T.; Doi, M.; Shigeta, H.; Muroga, Y.; Hosoe, S.; Numata, A.; Tanaka, R. Absolute stereostructures of cytotoxic metabolites, chaetomugilins A-C, produced by a Chaetomium species separated from a marine fish. Tetrahedron Lett. 2008, 49, 4192-4195.

7. Muroga, Y.; Yamada, T.; Numata, A.; Tanaka, R. Chaetomugilins, new selectively cytotoxic metabolites, produced by a marine fish-derived Chaetomium species. J. Antibiotics 2008, 61, 615622 and references on other azaphilones cited therein. 
8. Yamori, T.; Matsunaga, A.; Sato, S.; Yamazaki, K.; Komi, A.; Ishizu, K.; Mita, I.; Edatsugi, H.; Matsuba, Y.; Takezawa, K.; Nakanishi, O.; Kohno, H.; Nakajima, Y.; Komatsu, H.; Andoh, T.; Tsuruo, T. Potent antitumor activity of MS-247, a novel DNA minor groove binder, evaluated by an in vitro and in vivo human cancer cell line panel. Cancer Res. 1999, 59, 4042-4049.

9. Yamori, T. Panel of human cancer cell lines provides valuable database for drug discovery and bioinformatics. Cancer Chemother. Pharmacol. 2003, 52, S74-S79.

10. Matsuzaki, K.; Tanaka, H.; Omura, S. Isochromophilones I and II, novel inhibition against gp120CD4 binding produced by Penicillium multicolor FO-2338. II Structure Elucidation. J. Antibiot. 1995, 48, 708-713.

11. Mathe, F.; Castanet, Y.; Mortreux, A.; Petit, F. Synthesis of 2-butanone from ethylene and methyl formate catalysed by rhodium-iodide complexes. Tetrahedron Lett. 1991, 32, 3989-3992.

(C) 2009 by the authors; licensee Molecular Diversity Preservation International, Basel, Switzerland. This article is an open-access article distributed under the terms and conditions of the Creative Commons Attribution license (http://creativecommons.org/licenses/by/3.0/). 